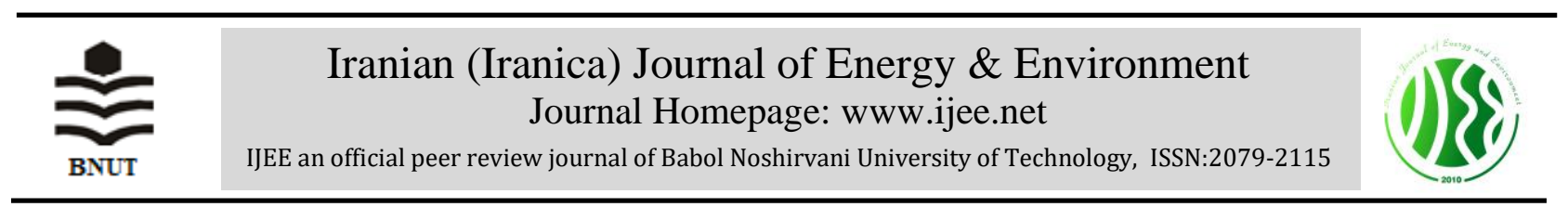

\title{
Performance Evaluation and Emission Characterization of Biodiesel from Shea Butter on Compression Ignition Engine
}

\author{
E. O. Ajala ${ }^{1 *}$, F. Aberuagba ${ }^{2}$, M. A. Ajala ${ }^{1}$, A. M. Ayanshola ${ }^{3}$, T. D. Akpenpuun ${ }^{4}$ \\ ${ }^{1}$ Department of Chemical Engineering, University of Ilorin, Ilorin, Nigeria \\ ${ }^{2}$ Department of Chemical Engineering, Federal University of Technology, Minna, Nigeria \\ ${ }^{3}$ Department of Water Resources and Environmental Enginerring, University of Ilorin, Ilorin, Nigeria \\ ${ }^{4}$ Department of Agricultural and Biosystems Engineering, University of Ilorin, Ilorin, Nigeria
}

\section{PAPER INFO}

Paper history:

Received 14 November 2019

Accepted in revised form 20 February 2020

\section{Keywords:}

Biodiesel

Compression Ignition Engine

Diesel

Emission

Performance

\begin{abstract}
A $B S S T R A C T$
Shea biodiesel (SBD) was produced and blended with diesel at various proportions to produce 100B (SBD), 75B, $50 \mathrm{~B}, 25 \mathrm{~B}$, and D (diesel) as fuel types. The SBD and other fuel types were characterised by ASTM standard methods for its physicochemical properties. The fuel types were used in a compression ignition engine (CIE) to test for fuel consumption (FC), specific fuel consumption (SFC), brake thermal efficiency (BTE), exhaust temperature (ET) and emission characteristics; hydrocarbon (HC), carbon dioxide $\left(\mathrm{CO}_{2}\right)$, carbon monoxide (CO), nitrogen oxide $\left(\mathrm{NO}_{\mathrm{x}}\right)$ and sulphur dioxide $\left(\mathrm{SO}_{2}\right)$. The physicochemical properties of SBD in terms of density, kinematic viscosity, flash point, cloud and pour points, and cetane number were $884.7 \mathrm{~kg} / \mathrm{m}^{3}, 5.69 \mathrm{~mm}^{2} / \mathrm{s}, 165$, $12,9^{\circ} \mathrm{C}$ and 55 , respectively; while those of diesel were $860.4 \mathrm{~kg} / \mathrm{m}^{3}, 2.6 \mathrm{~mm}^{2} / \mathrm{s}, 73,2.4,-9^{\circ} \mathrm{C}$ and 49 , respectively. The results were within the range of the standard. The results obtained at $12 \mathrm{Nm}$ torque for SFC, FC, BTE, and ET for SBD were $0.21 \mathrm{~kg} / \mathrm{kW} . \mathrm{h}, 0.71 \mathrm{~kg} / \mathrm{h}, 12.69 \%$, and $365^{\circ} \mathrm{C}$, respectively, while those of diesel were $0.31 \mathrm{~kg} / \mathrm{kW} . \mathrm{h}$, $1.12 \mathrm{~kg} / \mathrm{h}, 8.46 \%$, and $330^{\circ} \mathrm{C}$, respectively. These results show that the SBD and diesel possessed similarity in terms of performance. The SBD is environmentally friendly compared to diesel. This study shows that the SBD possessed quality alternative replacement to diesel suitable for a CIE.
\end{abstract}

doi: 10.5829/ijee.2020.11.01.10

\section{INTRODUCTION}

Environmental issues associated with the increasing usage of fossil fuels and the progressive depletion of fossil fuels have necessitated the need for alternative fuel that is more ecofriendly, renewable and sustainable than fossil fuels [1]. Biodiesel is the most widely accepted alternative fuel for diesel engines as it is technically feasible, economically competitive, environmentally acceptable, readily available and strategic advantages. It is the first alternative fuel that passed the US EPA-required Tier I and Tier II Health Effects testing requirements of the Clean Air Act Amendments of 1990 [2, 3]. Comparatively, biodiesel is more lubricating than petroleum diesel thereby reducing engine wear and tear. Relative to petroleum diesel, biodiesel slightly reduces peak engine power $(\sim 4 \%)$ at low engine speed and causes the torque curves to flatter. Biodiesel on average decrease power by $5 \%$ in comparison to diesel at rated load [4]. It contains practically no sulphur but it is rich in oxygen (usually 10 to $12 \%$ ) than petroleum diesel, which eventually results in lower pollution emissions, improved biodegradability, reduced toxicity, and higher cetane rating. Apart from the aforementioned, the use of biodiesel in CIE improves engine performance.

Biodiesel is produced from vegetable oil or animal fats and generally has higher density, higher viscosity, higher cloud point, higher cetane number, lower volatility, and heating value compared to commercial grades of diesel fuel $[2,5]$. The biodiesel exhibits better degradation characteristic and lower emissions of carbon monoxide (CO), carbon dioxide $\left(\mathrm{CO}_{2}\right)$, total hydrocarbons (THCs), particulate matter (PM) and volatile organic compounds (VOC) [6], but it produces a higher concentration of nitrogen oxides (NOx) emissions [7]. Although biodiesel has become more attractive in recent times because of its environmental benefits. However, the quality of biodiesel depends on the source and the physicochemical properties of vegetable oil/animal fat. The physicochemical properties of the oil/fat include viscosity, density, iodine values, specific gravity, peroxide value, percentage free fatty acid, acid value, saponification value, and $\mathrm{pH}$ values. It has been reported that high viscosity of vegetable oil/animal fat causes poor fuel atomization in 
CIE which results in the improper fuel-air mixture and inefficient combustion [8, 9]. Higher viscosity and cloud point in biodiesel could also be a problem in a diesel engine as it affects the fuel droplet size (larger droplets) during injection which has been reported as possible causes of higher NOx emissions [10]. Poor quality biodiesel can lead to many problems in engine performance and care should be taken to ensure that the fuel produced is of high quality [11].

Biodiesel can be used in its pure form or blended with diesel fuel in any proportion for use in CIE [12]. Although biodiesel is miscible with petroleum diesel in any proportion, not all blended proportions are suitable in diesel engines. Enweremadu et al. [2] reported that biodiesel blended up to $5 \%$ should not cause engine and fuel system problems. The use of biodiesel in CIE requires little or no modification to the engine [13], as the biodiesel blends provide vehicles with the same horsepower, acceleration, and fuel economy as diesel fuel. However, the energy content of biodiesel is about $10 \%$ less than that of diesel. So, CIE powered with B100 is likely to have a slightly lower range of power compared to diesel. Biodiesel blends have very high lubricating qualities and many users report lower maintenance costs and increased mileage. Therefore, the use of alternative fuel in CIE can only be considered feasible or acceptable if engine performance is maintained in accordance with the specification. The three points of interest when determining engine performance include brake-specific fuel consumption (BSFC), brake effective power (BEP) and thermal efficiency. Since the energy content of biodiesel is approximately $10 \%$ lower than that of petrodiesel, it is expected that, in certain situations, engines fueled with biodiesel will not produce the same power that is produced as petroleum diesel. At full-load conditions with the wide-open throttle or at intermediate loads with equal fuel consumption or accelerator position, the power output should reduce with respect to energy content. Contrary to the expected, researchers have reported different results. Some authors have reported a lower decrease in power output than expected when using biodiesel, while some have reported power loss in the same scope as reduced energy content. In terms of rated power and torque, some researchers have reported high rated power and torque, while some reported no significant difference in output power and torque [14].

Cetinkaya et al. [15] observed that the reduction of torque ranged between 3 to $5 \%$ when comparing waste oil biodiesel to petroleum diesel in a $75 \mathrm{~kW}$ four-cylinder common rail engine. Lin et al. [16] found out that the power at full load when using biodiesel produced from pure palm oil was only $3.5 \%$ less than that of the petroleum diesel in a $2.84 \mathrm{~L}$ naturally aspirated engine. Usta [17] observed an increase in torque and power when fueling an indirect injection diesel engine with tobacco biodiesel blends. Yücesu and Ílkilic [18] observed that the heating value for biodiesel produced from cotton-seed oil was only $5 \%$ less than the heating value of petrodiesel. Power and torque were observed to be reduced by $3-8 \%$ when using biodiesel produced from pure cotton-seed oil. Powell [19] reported that power loss is similar to the percentage reduction in heating value when using biodiesel produced from cooking oil. In addition, there is no significant difference in rated power when using rapeseed and soybean biodiesel blends in a 6-cylinder DDC engine. Moreover, no significant differences when using biodiesel produced from cotton-seed oil at several speeds in a single cylinder $2.75 \mathrm{~kW}$ engine. Therefore, the reason for the difference in the torque and power as was reported may be due to the difference in the vegetable oil used for biodiesel production. As various vegetable oil may have various energy contents.

Present study aimed to produce biodiesel from shea butter. The SBD was blended with a various proportion of diesel and were characterised for their physicochemical properties. The SBD, diesel and SBD-diesel blends were investigated on CIE by analyzing the engine performance and emission characteristics.

\section{MATERIAL AND METHODS \\ Materials}

Shea butter (SB) with the free fatty acid of $6.85 \%$ was purchased from Ilorin South Local Government of Kwara State and used for biodiesel production. A reactor developed as part of the study with $4.5 \mathrm{~L}$ capacity was used for biodiesel production. Analytical grades of methanol and potassium hydroxide were the reagents used in the study. Diesel was purchased from Nigeria National Petroleum Corporation, Mega station, Tanke, Ilorin, Kwara State. Exhaust emission test was investigated using various devices such as ToxiRAE Pro PGM-1850 $\mathrm{NO}_{2}$ and $\mathrm{CO}_{2}$, ToxiRAE Pro PGM$1860 \mathrm{SO}_{2}$, Seitron Portable Instrument, SP 300 Smart Portable Gas Detector, Model PORRDZB100SE, and Gunson, Gastester Digital CO, Model G4125 Vehicle Exhaust-Gas Analyser.

\section{Description of compression ignition engine (CIE) rig}

The biodiesel produced was tested for its performance using a $7.5 \mathrm{~kW}$ (10.05hp), single-cylinder, four-stroke, Compression Ignition Engine (CIE) incorporated with a water dynamometer machine. The detail configuration of the machine is shown in Table 1, while Figure 1 (plates (a) and (b) shows the CIE and data logger, and dynamometer respectively.

TABLE 1. Technical specification of compression ignition engine rig

\begin{tabular}{lc}
\hline Items & Specifications \\
\hline Model & TD115 \\
Type & $\begin{array}{c}\text { Single cylinder four-stroke, air- } \\
\text { cooled } \\
\text { Rated power }\end{array}$ \\
Rated speed & $7.5 \mathrm{~kW}(10.05 \mathrm{hp})$ \\
Maximum Torque & $6000 \mathrm{rpm}$ \\
Method of cooling & $12 \mathrm{Nm}$ \\
Starting method & Air cooling \\
Manufacturer & Manual cranking \\
Maximum operating capacity & TecQuipment Ltd. Nottingham, \\
A.C & England \\
Maximum operating capacity & $220 \mathrm{~V}, 50 \mathrm{~Hz}$ \\
D.C & $12 \mathrm{~V}, 10 \mathrm{~A}$ \\
\hline
\end{tabular}




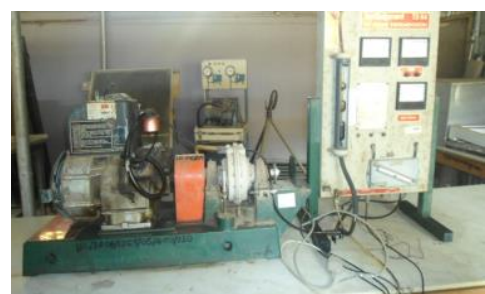

(a)

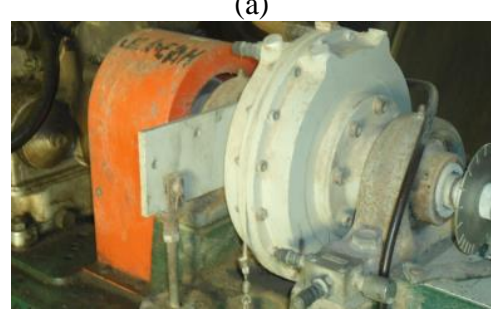

(b)

Figure 1. Plate (a). Compression ignition engine (CIE) Rig, plate (b). Dynamometer arm

\section{Shea biodiesel production in one-pot synthesis}

Shea biodiesel was produced in accordance with the method described by Ajala et al. [20]. When the biodiesel was produced, the product was discharged and poured into separating funnel for $48 \mathrm{~h}$. Biodiesel from the SB was separated from glycerol to obtain crude biodiesel. The obtained crude biodiesel was purified by washing and further purification process and identified as shea biodiesel (SBD).

\section{Characterization of SBD and various blends with diesel}

The characterization was necessary in order to evaluate the suitability of SBD and the various blends as a replacement for diesel. The standard methods of ASTMD were employed for the characterization of the SBD and the various blends of SBD with diesel. The various fuel types investigated were 100B, 75B, 50B, 25B, and D (Diesel). The physicochemical properties characterized were density, specific gravity, kinematic viscosity, cloud point, pour point, cetane index, aniline, total sulphur, and water content. Others are total acid value, colour, boiling point, recovery, residue, and loss.

\section{Experimental procedure of SBD utilization on CIE rig}

The performance of the engine using the various fuel types was evaluated. For each fuel blend, the engine was put on and allowed to warm up for $5 \mathrm{~min}$ at half throttle. The throttle was increased until the engine reached the wide-open throttle. Once wide-open throttle was attained, the engine was loaded with a different torque. The following torque; 0, 2, 4, 6, 8, 10 and $12 \mathrm{Nm}$ were considered. The engine was allowed to run upon the application of each torque until torque and corresponding speed was stable for at least $2 \mathrm{~min}$ for each of the fuel type investigated. Once the data loggers were stabilized, data collection was initiated and exhaust emissions were analyzed using various gas monitors. Upon completion of data collection, the load on the engine was increased while maintaining a wide-open throttle. The testing process was repeated for each torque for the duration of $20 \mathrm{~min}$. The engine power, fuel consumption, brake-specific fuel consumption, brake specific energy consumption, and brake thermal efficiency were calculated using Equations (1) to (5), respectively. engine power $($ watts $)=T \times \omega$

where $\mathrm{T}$ is the shaft torque in $\mathrm{Nm}$ and $\omega$ is the rotational speed in $\mathrm{rad} / \mathrm{s}$.

$$
\begin{aligned}
& \text { fuel consumption }\left(\frac{g}{h}\right)=\frac{\text { fuel consumed }}{\text { time }} \\
& \text { brake specific fuel consumption }\left(\frac{g}{k w h}\right)= \\
& \frac{f}{0.1047 \times N \times 0.001 \times T}
\end{aligned}
$$

where $\mathrm{f}$ is the fuel consumption $(\mathrm{g} / \mathrm{h}), \mathrm{N}$ is the speed $(\mathrm{rpm})$ and $\mathrm{T}$ is the torque $(\mathrm{Nm})$.

$$
\text { brake specific energy consumption }=B S F C \times C V
$$

where BSFC is the brake specific fuel consumption $(\mathrm{g} / \mathrm{kwh})$ and $\mathrm{CV}$ is the calorific value of the oil (shea butter = 37.94).

$$
\begin{gathered}
\text { brake thermal efficiency } \\
\text { output power }
\end{gathered}
$$

The exhaust emission test was conducted concurrently with the performance test using the ToxiRAE Pro PGM-1850 and ToxiRAE Pro PGM-1860 for $\mathrm{NO}_{2} / \mathrm{CO}_{2}$ and $\mathrm{SO}_{2}$, respectively. The hydrocarbon emissions (THC) were determined using the Seitron Portable Instrument and Carbon monoxide was measured using the Gunson Gastester Digital $\mathrm{CO}$ Analyser. Exhaust concentrations of $\mathrm{NO}_{\mathrm{X}}, \mathrm{CO}_{2}, \mathrm{SO}_{2}$, and THC were measured in part per million (ppm) while $\mathrm{CO}$ was measured in percentage $(\%)$.

\section{RESULTS AND DISCUSSION}

Physicochemical properties of SBD and its various blends with diesel

The physicochemical properties of SBD and its various blends with diesel (100B, 75B, 50B, 25B, and D) are shown in Table 2.

The density of 100B, 75B, 50B, 25B and D was 884.7, $879.2,871.5,868.7$ and $860.4 \mathrm{~kg} / \mathrm{m}^{3}$, respectively. These results show that as the ratio of the diesel increases in the blend, the density decrease. This is an indication that the weight of fuel that would be delivered to the cylinder is higher in 100B, followed by $75 \mathrm{~B}$ and the least is D [21]. Hence, 100B with a higher density would deliver a greater mass of fuel into the combustion chamber of the engine than other blends, and this, in turn, produces more power and emissions [22-24]. However, in all the various fuel blends, the density is within the range of $860-900 \mathrm{~kg} / \mathrm{m}^{3}$ (ASTM standard). Biodiesel within this range of the standard for density is favorable for atomization in a diesel engine [25].

The kinematic viscosity obtained was 5.69, 5.35, 5.10, 3.4 and $2.6 \mathrm{~mm}^{2} / \mathrm{s}$ for $100 \mathrm{~B}, 75 \mathrm{~B}, 50 \mathrm{~B}, 25 \mathrm{~B}$ and $\mathrm{D}$, respectively. These results are within the range of $1.9-6.0 \mathrm{~mm}^{2} / \mathrm{s}$ recommended by the ASTM for the viscosity of biodiesel. The highest viscosity was recorded for $100 \mathrm{~B}$ and it shows good lubricating property above other blends. This reduces wears and tears of CIE. However, 100B with higher viscosity may cause engine deposits, poor fuel combustion and poor operations of the fuel injection system. It can lead to incomplete combustion and increases carbon deposits. This 
TABLE 2. Physicochemical properties of various blends of shea biodiesel with diesel

\begin{tabular}{|c|c|c|c|c|c|c|c|}
\hline Property & $100 \mathrm{~B}$ & $75 B$ & $50 B$ & 25B & D & ASTM method & Limits \\
\hline Density kg/m $\mathrm{m}^{3} @ 15^{\circ} \mathrm{C}$ & 884.7 & 879.2 & 871.5 & 868.7 & 860.4 & $4052-11$ & $860-900$ \\
\hline Kin.V.* mm²/s@40 ${ }^{\circ} \mathrm{C}$ & 5.69 & 5.35 & 5.10 & 3.4 & 2.6 & $445-12$ & $1.9-6.0$ \\
\hline Flash point $\left({ }^{\circ} \mathrm{C}\right)$ & 165.0 & 97.0 & 87.0 & 74.0 & 73.0 & $93-02 a$ & $130 \mathrm{~min}$ \\
\hline Cloud point $\left({ }^{\circ} \mathrm{C}\right)$ & 12 & 11 & 7 & 5 & 2.4 & $2500-11$ & $-3-12$ \\
\hline Pour point $\left({ }^{\circ} \mathrm{C}\right)$ & 9 & 8 & 3 & -1 & -9 & $97-12$ & $-15-10$ \\
\hline Cetane & 55 & 52 & 50 & 50 & 49 & $976-11$ & $47-60$ \\
\hline Total sulphur (\%wt) & 0.001 & 0.055 & 0.134 & 0.211 & 0.300 & 4294-10 & $0.005 \max$ \\
\hline Water content (\%vol.) & $<0.05$ & $<0.05$ & $<0.05$ & $<0.05$ & $<0.05$ & $95-13$ & $0.05 \max$ \\
\hline Colour & $\mathrm{L} 1.0$ & $\mathrm{~L} 1.5$ & $\mathrm{~L} 2.0$ & $\mathrm{~L} 2.0$ & $\mathrm{~L} 2.0$ & $1500-12$ & $\mathrm{~L} 2.0$ \\
\hline Distillation IBP & 280.0 & 180.0 & 176.0 & 170.0 & 158.0 & $86-12$ & \\
\hline Distillation $90 \%$ recovery ${ }^{\circ} \mathrm{C}$ & 384.0 & 341.0 & 340.0 & 340.0 & 341.0 & - & $360 \max$ \\
\hline Distillation FBP & 393.0 & 349.0 & 342.0 & 345.0 & 365.0 & - & \\
\hline Recovery (\%) & 98.5 & 98.5 & 98.5 & 98.5 & 98.5 & - & $90 \mathrm{~min}$ \\
\hline Residue & 1.0 & 1.0 & 1.0 & 1.0 & 1.0 & - & \\
\hline Loss & 0.5 & 0.5 & 0.5 & 0.5 & 0.5 & - & \\
\hline
\end{tabular}

shows that the other fuel types might be preferred, as it will overcome the aforementioned likely challenges with the 100B. However, the D with low viscosity may also cause an increase in fuel leakage between the pump plunger and barrel, and as a result, leads to a hot start and low fuel. This makes the engine difficult to start particularly if the pump is wornout $[23,26]$. Moreover, when the viscosity of fuel is low, the engine would not perform at its full designed capacity, since the pump would not deliver the quantity of fuel required. Therefore, SBD blends with diesel fuel are preferable in CIE for maximum power delivery, low wear and tear, and improved engine life-span.

Flash point measured for $100 \mathrm{~B}, 75 \mathrm{~B}, 50 \mathrm{~B}, 25 \mathrm{~B}$ and $\mathrm{D}$ was $165,97,87,74$ and $73^{\circ} \mathrm{C}$. Whereas, the ASTM specification of flash point is $130^{\circ} \mathrm{C}$ minimum. This value is to restrict the amount of alcohol in the biodiesel fuel to a maximum of about $0.1 \%$. For this study, SBD (100B) with a flash point of $165^{\circ} \mathrm{C}$ is above the minimum ASTM standard, an indication that it is considered safe for storage and transportation. However, the flash point decreases as the quantity of diesel increased in the various blends of shea biodiesel and diesel.

Cloud point $(\mathrm{CP})$ is a measure of temperature at which wax first appears visible when fuel is cooled, while pour point (PP) is the lowest temperature at which fuel can flow $[26,27]$. The cloud and pour points of 100B, 75B, 50B, 25B, and $\mathrm{D}$ were $12,11,7,5$ and 2.4 , and $9,8,3,-1$ and -9 respectively. The ranges for ASTM specifications are -3-12 and $-15-10^{\circ} \mathrm{C}$, respectively. The obtained $\mathrm{CP}$ and $\mathrm{PP}$ values for the various blends of shea biodiesel fall within the range.

The results show that the SBD and its various blends can be deployed in a relatively cold region, as the cloud point determines the operability of the fuels in a low-temperature region. The fuels can operate conveniently at temperatures of their cloud point. However, at an ambient temperature lower than the cloud and pour points of any of the fuels, the fuel begins to freeze and leads to blockage of fuel lines and filters thereby starve the engine of fuel and stop working.
Cetane values obtained in this study are 55, 52, 50, 50 and 49 for 100B, 75B, 50B, 25B, and D respectively, which are within the standard range of 47-60. These results showed that all the various blends of fuels have good ignition quality. This is because the cetane number indicates the quality of the compression ignition of fuels. Since the higher the cetane number of any fuel, the shorter the ignition delays time and the higher the tendency to ignite. In addition, duration of combustion, less occurrence of knocking, and lower formation of nitrogen oxides also depend on the cetane value of the fuel $[21,26]$. However, a higher cetane number could lead to a lower NOx emission of fuel [1]. In this study, cetane number of the SBD is higher compared with that of diesel.

The sulphur content of the SBD is 0.001 (\% mass), which is below the maximum standard $(0.005 \%$ mass $)$. However, as the proportion of diesel in the blends increases, the sulphur content increase from $0.055(75 \mathrm{~B})$ to $0.211(25 \mathrm{~B})$ and 0.300 (D). These values are higher than the maximum standard of $0.005 \%$. These further confirm that biodiesel is more environmentally friendly than diesel as it contains little or no sulphur content [28, 29]. Therefore, SBD is suitable for compression ignition engines as it would not damage the diesel engine and emit harmful gases into the environment.

The water content in SBD and other fuel blends are $<0.05 \%$ volume (Table 2), which falls below the ASTM specification. The water content in the fuel above the maximum would degrade the fuel and lead to the formation of whitish solid substances, which would clog the fuel filters, and disturb the flow of fuel to the engine. Furthermore, the presence of water in fuel above the limit would encourage microbial growth and cause tank and engine corrosion. Excessive water in biodiesel can also react with the free fatty acids to form an acidic solution that can promote corrosion of fuel equipment metallic components. Therefore, SBD and its various blends are regarded as suitable biodiesel for the compression ignition engine without fear of damage to the engine components. 
The colour of biodiesel generally changes with transesterification, but becomes darker when blends with diesel as presented in Table 2. The colour of the SBD was L1.0, while that of the diesel was L2.0. The various blends of fuel fall within L1.0 and L2.0. These results are within the standard limit of L2.0. The SBD is closer to the standard than that of diesel as shown in Table 2.

The recommended distillation temperature of biodiesel is $360^{\circ} \mathrm{C}$. This is the maximum temperature at which $90 \%$ of a $200 \mathrm{ml}$ sample would be distilled. This test was developed to determine the distillation characteristics of petroleum products and was chosen by ASTM to be included in the biodiesel specification [26]. The SBD measured $384^{\circ} \mathrm{C}$ while diesel recorded $341^{\circ} \mathrm{C}$. These showed that the SBD is above the maximum specification limit, but the other blends were below the limit as shown in Table 2. This parameter depends on the boiling point of fuel as it affects the combustion characteristics of diesel engines and can be used to measure the cetane number of biodiesel and other similar fuels [21].

\section{Engine performance of SBD and its various blends with diesel (D)}

Figure 2 shows the effect of torque on the engine power of $\mathrm{SBD}$ and its various blends. It was observed that as torque increases, the engine power increase. The pattern of the figure revealed that the engine power was low at initial torque, and increased with the increase in torque (for all fuel types tested). The plots also showed that the engine power for diesel $(3.6 \mathrm{~kW})$ is almost the same as that of SBD $(3.4 \mathrm{~kW})$ and its various blends when the highest torque of $12 \mathrm{Nm}$ was used. Almost the same value of engine power was obtained at the lowest torque of $2 \mathrm{Nm}$ for diesel and SBD which were 0.67 and $0.58 \mathrm{~kW}$, respectively. This is due to the greater calorific value of diesel in comparison to the SBD and its blends [30].

Specific fuel consumption (SFC) is the ratio between the mass of fuel consumed and the brake effective power produced by an engine. The SFC is inversely proportional to thermal efficiency [14]. Figure 3 shows the effect of torque on SFC for SBD and its various blends. For minimum torque of 0 and maximum torque of $12 \mathrm{Nm}$, SFC for SBD was 1.24 and $0.21 \mathrm{~kg} / \mathrm{kW} \mathrm{h}$, and for diesel was 1.41 and $0.31 \mathrm{~kg} / \mathrm{kW} \mathrm{h}$ respectively. This value for SBD is a little lower than that of diesel at any given torque, but higher when Waste Pork Lard Methyl Ester (WPLME) was used at minimum load $(0.7 \mathrm{~kg} / \mathrm{kW} . \mathrm{h})$ and maximum load $(0.35 \mathrm{~kg} / \mathrm{kW} . \mathrm{h})$ [1]. It was

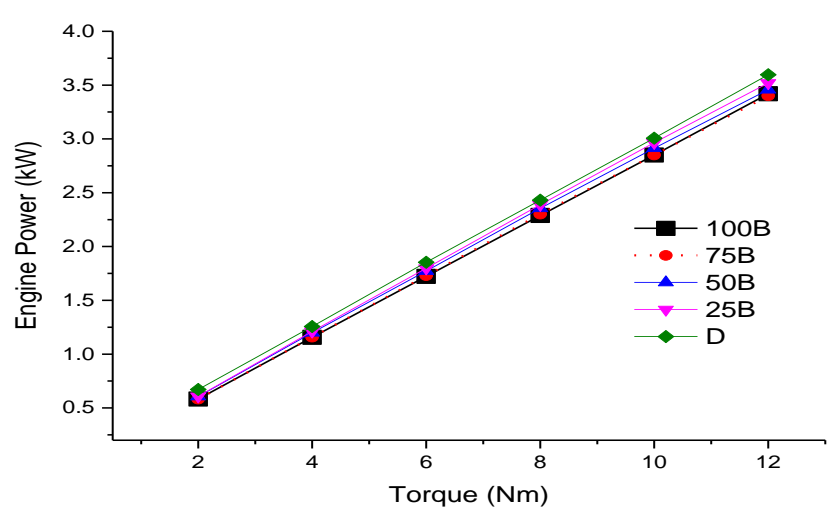

Figure 2. Engine power against torque of SBD (100B) and its various blends also noticed that the SFC of the SBD and its blends were slightly lower than that of diesel under torque range of 0 to 12 $(\mathrm{Nm})$, but increases with increase in diesel for all the fuel types for each of the torque. This slight difference of SFC at low load for the blends and diesel is due to higher density and viscosity of SBD [31]. This indicates lower fuel consumption per unit power produced [32].

Powell [19] also reported that the increase in the SFC for biodiesel is attributed to oxygen enrichment from fuel and not from the intake of air. Buyukkaya [33] reported a similar trend in the SFC as compared between SBD and diesel.

Figure 4 shows the effect of torque on fuel consumption for SBD and its various blends. It was observed that the consumption of fuel increases with an increase in torque from 0 to $12 \mathrm{Nm}$. The fuel consumption rate of SBD and its various blends were lower than that of diesel in all the torque. This may be due to the presence of fatty acid profiles in the SBD. At low engine torque $(0 \mathrm{Nm})$, the fuel consumption rate for SBD (100B) and diesel were 0.47 and $0.72 \mathrm{~kg} / \mathrm{hr}$ respectively, while at full engine torque $(12 \mathrm{Nm})$, it was 0.71 and $1.12 \mathrm{~kg} / \mathrm{hr}$ respectively. These results show that as the SBD quantity increases in the blends, the fuel consumption decreases. This may be due to higher energy content and the presence of oxygen in the SBD. This allows for complete combustion of fuel in the engine and from these findings, SBD has shown greater fuel economy than diesel.

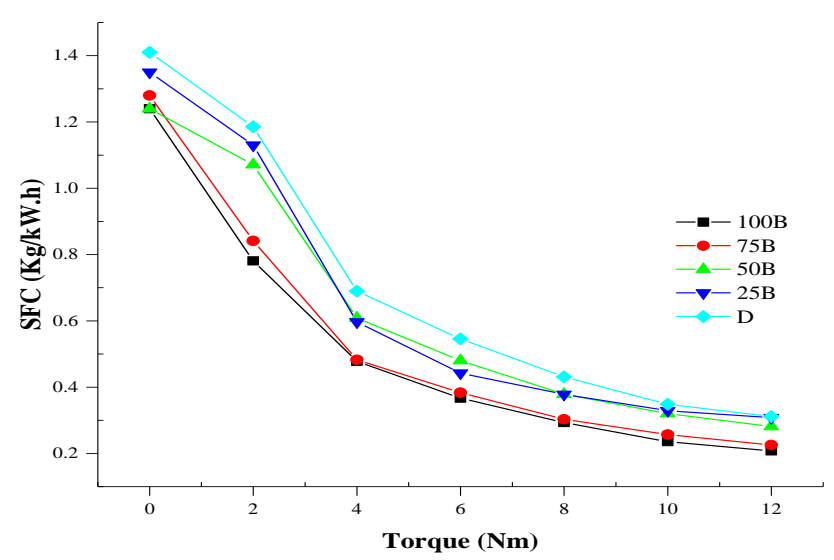

Figure 3. Effect of torque on SFC of SBD (100B) and its various blends

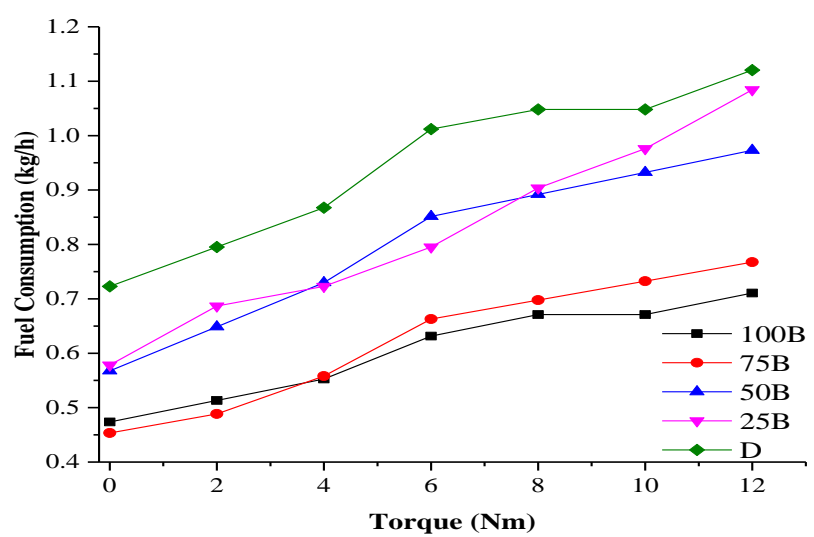

Figure 4. Effect of engine torque on fuel consumption of SBD and its various blends 
Brake Thermal Efficiency (BTE) is defined as the ratio of power output to the energy introduced through fuel injection. Figure 5 presents the BTE of SBD and its various blends against torque. It shows that the BTE of all the fuel types increases with an increase in torque from 0 to $12 \mathrm{Nm}$. It was also noticed that the BTE of all the fuel types is the same at low torque. However, at higher torque, the BTE of SBD is slightly higher than that of diesel and at the highest torque of $12 \mathrm{Nm}$, BTE of SBD (12.69\%) was much higher than that of diesel $(8.46 \%)$. This is due to a higher viscosity and higher density of SBD than that of the diesel, as the higher viscosity leads to decreased atomization and fuel vaporization [1].

The effect of torque on exhaust temperature for SBD and its various blends is shown in Figure 6. The graph shows that the exhaust temperature increases with an increase in torque. The exhaust temperature of SBD is higher than diesel at lower and higher torque, but the same at about $6 \mathrm{Nm}$ [30]. The higher exhaust temperature of SBD may be due to high flash point and high viscosity [28]. Higher oxygen content in the SBD is also responsible for the higher exhaust temperature in SBD compared to diesel [30].

\section{Emission characterization of SBD and its various blends} with diesel from CIE

The emission from compression of SBD and its various blends in CIE (Diesel engine) was investigated and the results are shown in Figures 7-11.

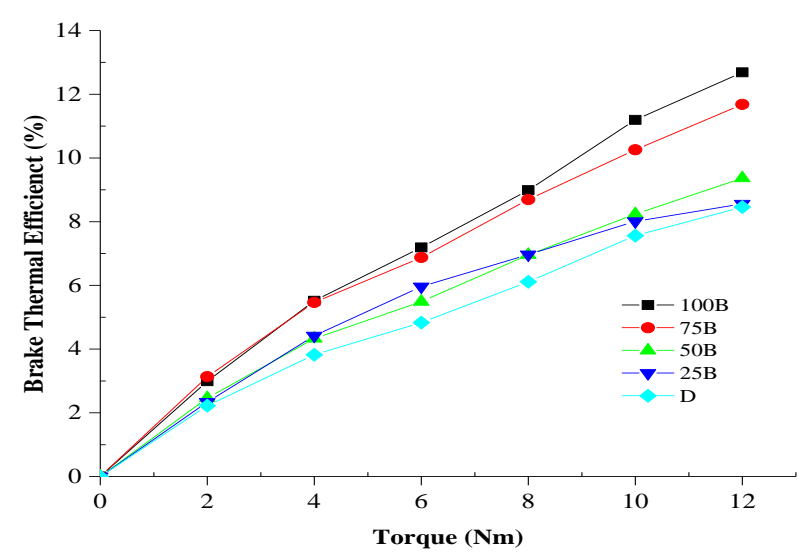

Figure 5. Effect of torque on brake thermal efficiency of SBD and its various blends

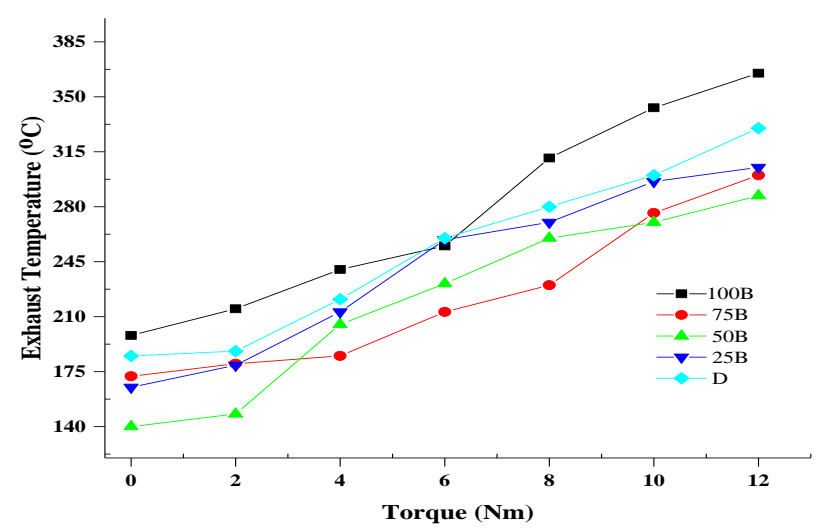

Figure 6. Effect of torque on exhaust temperature of SBD and its various blends

\section{Hydrocarbon (HC) emission}

Figure 7 shows the variation of $\mathrm{HC}$ emission with engine torque for various blends of SBD with diesel. The figure shows that $\mathrm{HC}$ emission for all the fuel types studied was lower at both low and high engine torques compare to diesel. This may be attributed to the less amount of carbon and hydrogen content of the SBD [28]. As well as the oxygen content, which is about $10-12 \%$ weight in SBD, while the oxygen content of diesel is negligible. This is because the presence of oxygen in biodiesel allows for complete combustion, which reduces HC emission [34]. The HC emission of $25 \mathrm{~B}$ and $50 \mathrm{~B}$ is relatively close to diesel. The lowest $\mathrm{HC}$ emission was observed for 100B.

\section{Nitrogen oxides (NOx) emission}

The NOx emission is a contributing factor in the localized formation of smog and ozone layer depletion. The variation of NOx emission with engine power for different blends of SBD and diesel is shown in Figure 8. It can be observed from the figure that the NOx emission of all the SBD blends is greater than that of diesel and increases with the engine power.

This may be due to the overall fuel-air ratio increase, which results in an increase in the average gas temperature in the combustion chamber, therefore encouraging NOx formation [35]. In order to increase the oxidative stability and reduction of NOx emissions, the amount of unsaturated fatty acid methyl esters in the SBD may have to be decreased [36, 37]. The application of SBD in a CIE, when compared to emissions from diesel, results in a substantial reduction of unburned $\mathrm{HC}$ and carbon monoxide. However, NOx emissions are slightly higher because NOx emission depends on the total oxygen and temperature inside the combustion chamber [1]. The presence of oxygen in SBD might have caused an increased in the formation of NOx. This is one of the disadvantages of biodiesel since NOx released are precursors to the destruction of the ozone layer as well as acidic rain [4].

\section{Carbon monoxide (CO) emission}

Figure 9 shows the variations of $\mathrm{CO}$ emissions with respect to a torque of the engine at various blends of SBD with diesel fuel. It was observed from the figure that the $\mathrm{CO}$ emission

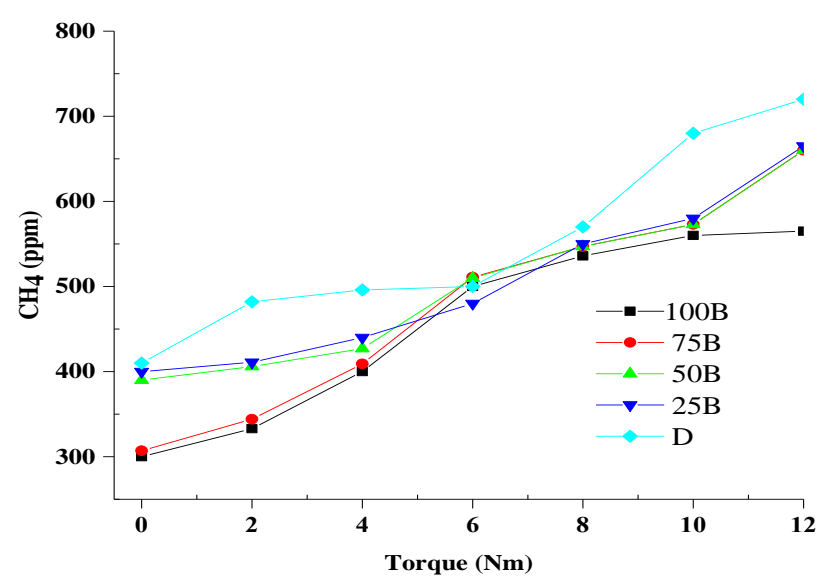

Figure 7. Effect of torques on hydrocarbon emission of SBD and its various blends 


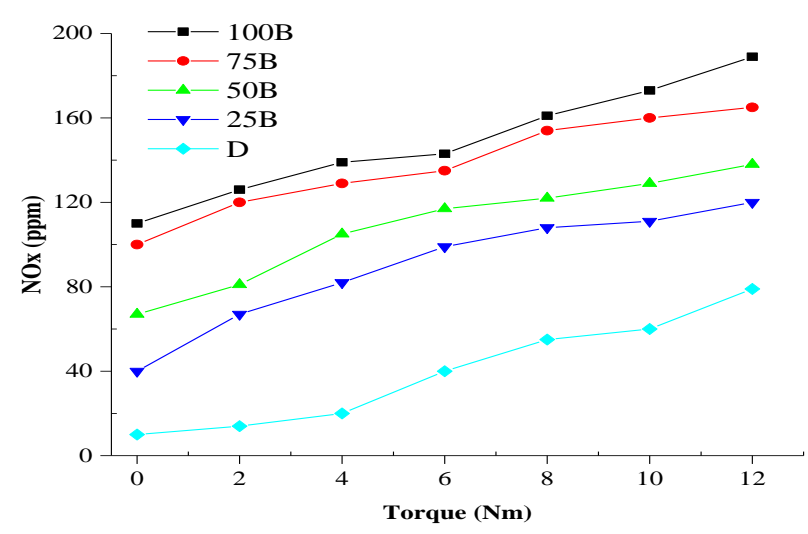

Figure 8. Effect of torque on $\mathrm{NO}_{\mathrm{x}}$ emission of $\mathrm{SBD}$ and its various blends

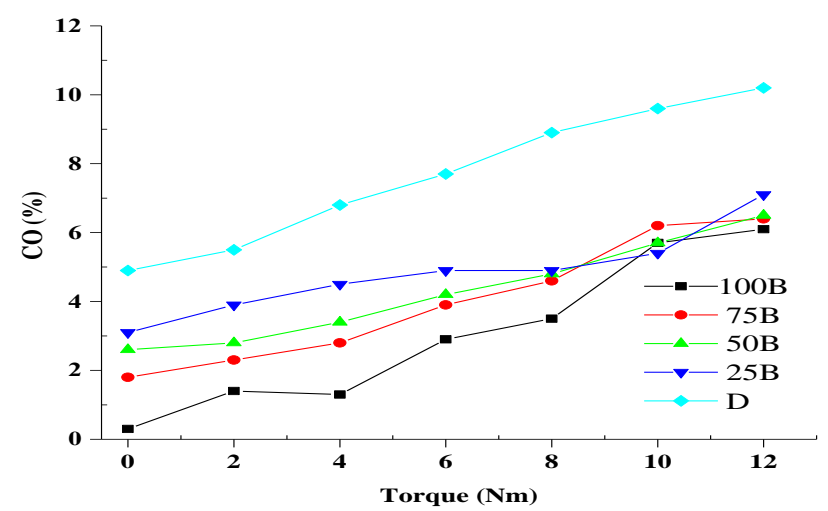

Figure 9. Effect of torque on CO (\%) emission of SBD and its various blends

increases with an increase in the engine torque. When the engine torque was low, the $\mathrm{CO}$ emission of all the blends were minimal. However, as the engine power increases, the $\mathrm{CO}$ emission of all the fuel types increased. At the full engine power, $\mathrm{CO}$ emission of SBD and its blends were almost the same. When CO emission of SBD and its various blends were compared with diesel, it was noticed that $\mathrm{CO}$ emission of SBD and its various blends were lower than diesel. This may be due to complete combustion because of complete oxidation. The CO emitted during combustion of SBD might have been converted to $\mathrm{CO}_{2}$ by taking up the extra oxygen molecules present in the SBD chain and thereby reducing $\mathrm{CO}$ formation [35]. This finding further corroborates the work of other researchers who reported that biodiesel provides more significant reductions in CO than diesel [38].

\section{Carbon dioxide $\left(\mathrm{CO}_{2}\right)$ emission}

Figure 10 presents the variation of $\mathrm{CO}_{2}$ emission with engine torque for different blends of SBD and diesel. From the figure, it was observed that the $\mathrm{CO}_{2}$ emission decreases with the increase in the engine torque. At low engine torque, the $\mathrm{CO}_{2}$ emission of SBD and its blends were higher compared to diesel. This may be due to complete combustion that takes place in the combustion chamber because of elemental oxygen content present in the vegetable oil [28]. At full engine torque, $\mathrm{CO}_{2}$ emission of all the fuel types were reduced compared to when engine torque was lower. This may also be due to the complete combustion of the fuels.

\section{Sulphur oxides $\left.\mathbf{S O}_{2}\right)$ emission}

The SOx are pungent, colourless gases formed primarily by the combustion of sulfur-containing fossil fuels. These SOx may have an impact on human health, damage vegetation and cause a serious environmental hazard [4]. Biodiesel and petrodiesel possess similar fuel properties but biodiesel contains no sulfur. The application of biodiesel in a conventional diesel engine is expected to produce a substantial reduction of the air pollutant from its combustion, which was further confirmed in this study as shown in Figure 11. The figure showed that $\mathrm{SO}_{2}$ emissions are reduced in direct proportion to the diesel replacement; hence, SBD has demonstrated good characteristics, including reduction of exhaust emissions.

Therefore, SBD and its various blends with diesel show lower emissions of carbon monoxides $\left(\mathrm{CO}\right.$ and $\left.\mathrm{CO}_{2}\right)$, total hydrocarbons $\left(\mathrm{THC}_{\mathrm{s}}\right)$ and $\mathrm{SO}_{2}$.

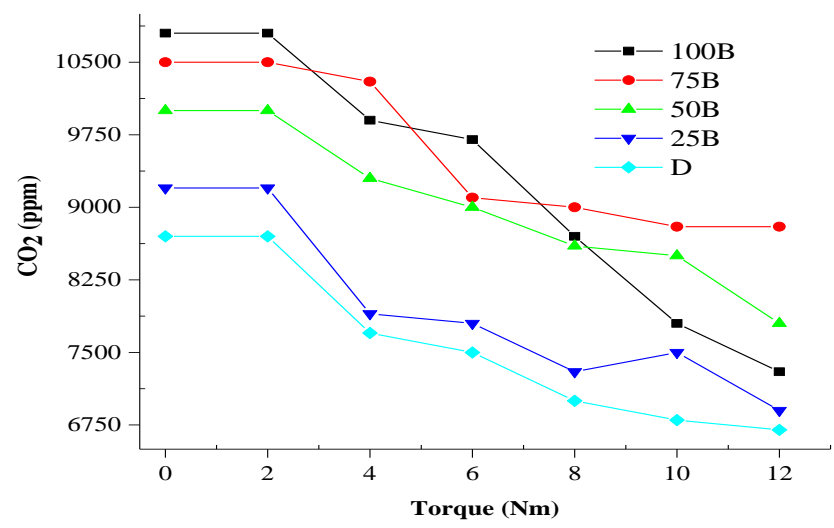

Figure 10. Effect of torque on $\mathrm{CO}_{2}$ emission of SBD and its various blends

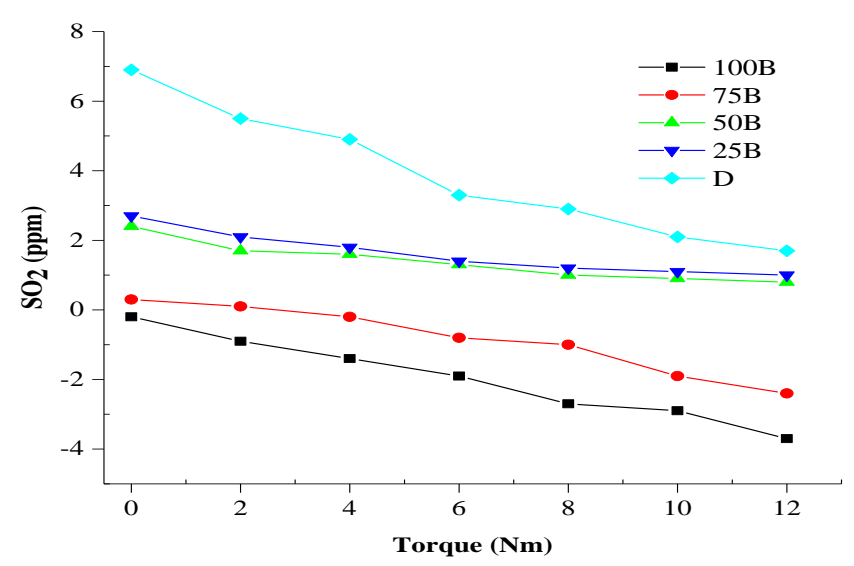

Figure 11. Effect of torque on $\mathrm{SO}_{2}$ emission of $\mathrm{SBD}$ and its various blends

\section{CONCLUSIONS}

The performance characteristics investigated for the SBD and its various blend of diesel on a CIE demonstrated that virtually all the characteristics studied are in close agreement with that of the diesel. The SFC increases with an increase in SBD quantity in the blends. 
The BTE of SBD and its blends are slightly higher than that of diesel when torque was $12 \mathrm{Nm}$ and tends toward the same value at lower torque. The CIE performance through the combustion characterization and the exhaust temperature revealed that the SBD is of great performance than diesel. The emission from the CIE further confirmed that SBD is environmentally friendly with lower $\mathrm{CO}, \mathrm{CO}_{2}, \mathrm{SO}_{2}$, and $\mathrm{HC}$. The CIE performed satisfactorily using the SBD and its blends with diesel fuel without any modification to the engine hardware. Based on this performance the SBD and its various blends can be adopted as alternative fuels to diesel. The study concluded that the SBD is suitable in CIE with great performance and minimal environmental pollution from the combustion process.

\section{REFERENCES}

1. Sathiyagnanam, A.P., Vijayaraj, K., and Saravanan, C.G., 2012 Biodiesel production from waste pork lard and an experimental investigation of its use as an alternate fuel in a di diesel engine. International Journal of Mechanical Engineering and Robotics Research, 1, pp.176-191.

2. Enweremadu, C.C., Rutto, H.L. and Peleowo, N., 2011. Performance evaluation of a diesel engine fueled with methyl ester of shea butter World Academy of Science, Engineering and Technology, 79, pp.142146.

3. Yuan, W., Hansen, A.C. and Zhang, Q., 2004. The Specific Gravity Of Biodiesel Fuels And Their Blends With Diesel Fuel. Agricultural Engineering International: CIGR Journal, 6, pp.1-11.

4. Demirbas, A., 2008. Biodiesel: A realistic fuel alternative for diesel engines. Springer-Verlag, London Limited.

5. Öner, C. and Altun, Ş., 2009. Biodiesel production from inedible animal tallow and an experimental investigation of its use as alternative fuel in a direct injection diesel engine. Applied Energy, 86(10), pp.2114-2120.

6. Lee, H.V., Taufiq-Yap, Y.H., Hussein, M.Z. and Yunus, R., 2013 Transesterification of jatropha oil with methanol over $\mathrm{Mg}-\mathrm{Zn}$ mixed metal oxide catalysts. Energy, 49, pp.12-18.

7. Fazal, M.A., Haseeb, A.S.M.A. and Masjuki, H.H., 2011. Biodiesel feasibility study: an evaluation of material compatibility; performance; emission and engine durability. Renewable and Sustainable Energy Reviews, 15(2), pp.1314-1324.

8. Bari, S., Yu, C.W. and Lim, T.H., 2002. Performance deterioration and durability issues while running a diesel engine with crude palm oil. Proceedings of the Institution of Mechanical Engineers, Part D: Journal of Automobile Engineering, 216(9), pp.785-79.

9. Saravanan, S., Nagarajan, G., Rao, G.L.N. and Sampath, S., 2007. Feasibility study of crude rice bran oil as a diesel substitute in a DI-CI engine without modifications. Energy for Sustainable Development, 11(3), pp.83-92.

10. Bajpai, D. and Tyagi, V.K., 2006. Biodiesel: source, production, composition, properties and its benefits. Journal of OLEo Science, 55(10), pp.487-502.

11. Ciolkosz, D., 2015, January. What's So Different about Biodiesel Fuel?. In Bioenergy, Academic Press, pp. 551-555.

12. Hofman, V., 2003. Biodiesel fuel. NDSU Extension Service, North Dakota State University of Agriculture. Applied Science and US Department of Agriculture cooperating, Fargo, North Dakota.

13. Diya'uddeen, B.H., Aziz, A.A., Daud, W.M.A.W. and Chakrabarti, M.H., 2012. Performance evaluation of biodiesel from used domestic waste oils: a review. Process Safety and Environmental Protection, 90(3), pp.164-179.

14. Lapuerta, M., Rodríguez-Fernández, J. and Agudelo, J.R., 2008. Diesel particulate emissions from used cooking oil biodiesel. Bioresource Technology, 99(4), pp.731-740.

15. Cetinkaya, M., Ulusoy, Y., Tekìn, Y. and Karaosmanoğlu, F., 2005. Engine and winter road test performances of used cooking oil originated biodiesel. Energy Conversion and Management, 46(7-8), pp.12791291.

16. Lin, Y.C., Lee, W.J., Wu, T.S. and Wang, C.T., 2006. Comparison of $\mathrm{PAH}$ and regulated harmful matter emissions from biodiesel blends and paraffinic fuel blends on engine accumulated mileage test. Fuel, 85(1718), pp.2516-2523.

17. Usta, N., 2005. Use of tobacco seed oil methyl ester in a turbocharged indirect injection diesel engine. Biomass and Bioenergy, 28(1), pp.7786.

18. Yücesu, H.S. and İlkiliç, C., 2006. Effect of cotton seed oil methyl ester on the performance and exhaust emission of a diesel engine. Energy Sources, Part A, 28(4), pp.389-398.

19. Powell, J.J., 2010. Engine performance and exhaust emissions from a diesel engine using cottonseed oil biodiesel. Doctoral dissertation, Texas A \& M University, United States.

20. Ajala, E.O., Olaniyan, A.M., Aberuagba, F., Ajala, M.A. and Odewole, M.M., 2017. One-pot synthesis of biodiesel from high FFA shea butter in an optimisation study using response surface methodology. Biofuels, pp.1-8.

21. Bello, E.I., Akinola, A.O., Otu, F. and Owoyemi, T.J., 2013. Fuel and Physiochemical Properties of Cashew (Anarcardium 1 occidentale) Nut Oil, Its Biodiesel and Blends with Diesel. Current Journal of Applied Science and Technology, pp.1055-1069.

22. Odin, E.M., Onoja, P.K. and Ochala, A.U., 2013. Effect of process variables on biodiesel production via transesterification of Quassia undulata seed oil, using homogeneous catalyst. International Journal of Scientific \& Technology Research, 2(9), pp.267-276.

23. Rao, G.L.N., Ramadhas, A.S., Nallusamy, N. and Sakthivel, P., 2010. Relationships among the physical properties of biodiesel and engine fuel system design requirement. International Journal of Energy and Environment, 1(5), pp.919-926.

24. Sivaramakrishnan, K. and Ravikumar, P., 2011. Determination of higher heating value of biodiesels. International Journal of Engineering Science and Technology, 3(11), pp.7981-7987.

25. Nitièma-Yefanova, S., Poupaert, J. H., Mignolet, E., Nébié, R. C. H. and Bonzi-Coulibaly, L. Y. (2012). Characterization of some nonconventional oils from Burkina Faso. Journal de la Société OuestAfricaine de Chimie, 33, pp. 67-71.

26. Ajala, E.O., Aberuagba, F., Olaniyan, A.M. and Onifade, K.R., 2015. Comparative study of acid-base and base catalysed processes of biodiesel production using high FFA shea butter. Journal of Basic and Applied Research International, 11, pp.87-96.

27. Bello, E.I., Mogaji, T.S. and Agge, M., 2011. The effects of transesterification on selected fuel properties of three vegetable oils. Journal of Mechanical Engineering Research, 3(7), pp.218-225.

28. Ghosh, S. and Dutta, D., 2012. Performance and exhaust emission analysis of direct injection diesel engine using pongamia oil. International Journal of Emerging Technology and Advanced Engineering, 2(12), pp.341-346.

29. Younis, K.A., Gardy, J.L. and Barzinji, K.S., 2014. Production and characterization of biodiesel from locally sourced sesame seed oil, used cooking oil and other commercial vegetable oils in Erbil-Iraqi Kurdistan. American Journal of Applied Chemistry, 2, pp. 105-111.

30. Chakrabarti, M.H. and Ali, M., 2009. Performance of compression ignition engine with Indigenous castor oil bio diesel in Pakistan. NED University Journal of Research, 6(1), pp.10-20.

31. Mishra, P.C., Nayak, S.K., Ghosh, D.P., Ukamanal, M. and Sahu, S.K., 2013. Performance characteristics of a diesel engine fuelled with biodiesel produced from mahua oil using additive. IOSR Journal of Mechanical and Civil Engineering (IOSR-JMCE), 8, pp.26-34.

32. Eze, J.I. and Elijah, I.R., 2010. Tested performance parameters of diesel fuel and transesterified shea nut oil blends in compression ignition engine. Global Journal of Researches in Engineering, 10, pp.84-92.

33. Buyukkaya, E., 2010. Effects of biodiesel on a DI diesel engine performance, emission and combustion characteristics. Fuel, 89(10), pp.3099-3105.

34. Myint, L.L. and El-Halwagi, M.M., 2009. Process analysis and optimization of biodiesel production from soybean oil. Clean Technologies and Environmental Policy, 11(3), pp.263-276.

35. Harinathareddy, M., Nageswara Reddy, P. and Vijayakumar Reddy, K., 
2013. Performance and Emission Characteristics of a Diesel Engine Operated on Mahua Oil Methyl Ester, Elixir Mechanical Engineering, 55, pp.12978-12982.

36. Knothe, G., 2006. Analyzing biodiesel: standards and other methods Journal of the American Oil Chemists' Society, 83(10), pp.823-833.

37. Refaat, A.A., 2009. Correlation between the chemical structure of biodiesel and its physical properties. International Journal of Environmental Science \& Technology, 6(4), pp.677-694.

38. Zheng, M., Mulenga, M.C., Reader, G.T., Wang, M., Ting, D.S. and Tjong, J., 2008. Biodiesel engine performance and emissions in low temperature combustion. Fuel, 87(6), pp.714-722.

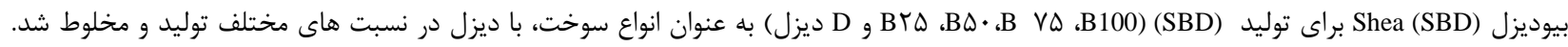

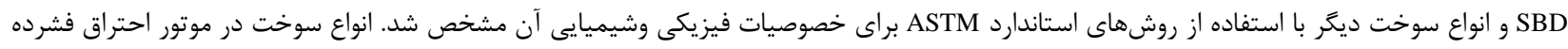

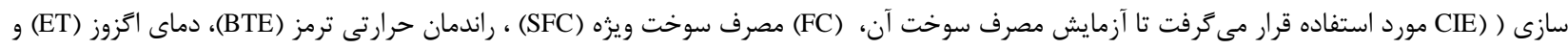

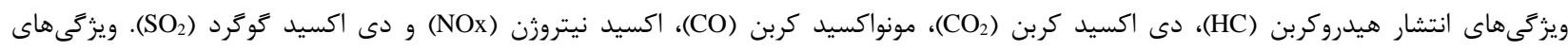

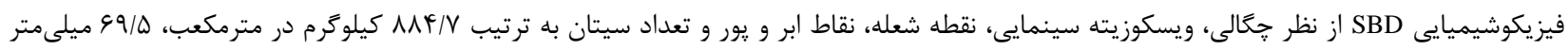

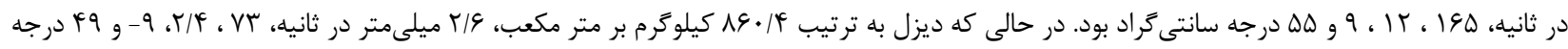

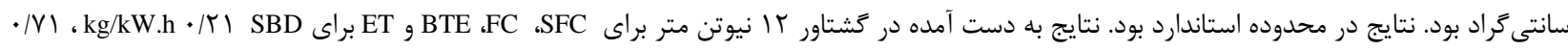

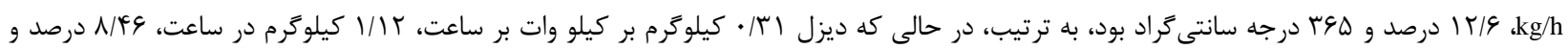

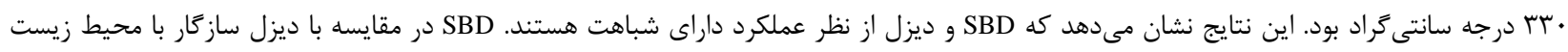

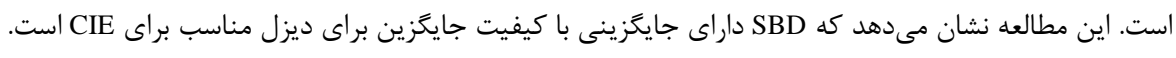

